\title{
Optimasi Penempatan Kapasitor Pada Sistem Tegangan Menengah Regional Jawa Barat
}

\author{
Herawati, Ys ${ }^{1}$, Gahara Nur E.P
}

\begin{abstract}
When the inductive reactive load is higher, it will cause a voltage drop, increase the power losses in the system, decrease the power factor and decrease the capacity of the electrical power distribution. To reduce the load of inductive reactive power, a capacitive reactive power source is needed by installing the capacitor with the optimal size and at the right location. The method used to determine the optimal size and location of fuzzy logic-genetic algorithm. The parameters used in this simulation are minimal channel power losses while still meeting the specified voltage limit, Vmin $=0.95$ PU and Vmax $=1.05$ PU. The test results show that the location of the optimal capacitor placement with fuzzy logic-genetic algorithm is on bus 11 and bus 12. The test result from the study of newton raphson power flow, determining the location capacitor with fuzzy logic and determining the optimal capacitor size with genetic algorithm takes about 4 minutes.
\end{abstract}

KEYWORD: Voltage Drop, Power Loss, Capacitors, Fuzzy Logic - Genetic Algorithm.

\begin{abstract}
ABSTRAK: Ketika beban reaktif induktif semakin tinggi maka akan menyebabkan menurunnya tegangan, memperbesar rugi-rugi daya pada sistem, menurunnya faktor daya serta menurunnya kapasitas penyaluran daya listrik. Untuk mengurangi beban daya reaktif induktif diperlukan sumber daya reaktif kapasitif yaitu dengan memasang kapasitor dengan ukuran yang optimal dan pada lokasi yang tepat. Metode yang digunakan untuk menentukan ukuran dan lokasi optimal yaitu fuzzy logic-agoritma genetika. Parameter yang digunakan pada simulasi ini yaitu rugi-rugi daya saluran minimal dengan tetap memenuhi batas tegangan yang ditentuka yaitu $\boldsymbol{V}_{\boldsymbol{m i n}}=0.95$ PU dan $\boldsymbol{V}_{\boldsymbol{m a x}}=1.05$ PU. Hasil pengujian menunjukan bahwa letak penempatan kapasitor yang optimal dengan fuzzy logic-algoritma genetika pada bus 11 dan bus 12 . Hasil pengujian dari studi aliran daya dengan Newton-Raphson, penentuan letak kapasitor dengan logika fuzzy, dan optimasi ukuran kapasitor dengan algoritma genetika membutuhkan waktu sekitar 4 menit.
\end{abstract}

KATA KUNCI: Tegangan Jatuh, Rugi Daya, Kapasitor, Fuzzy Logic -Algoritma Genetika.

\section{PENDAHULUAN}

$\mathrm{P}$ eningkatan permintaan suplai daya reaktif akibat pertumbuhan beban yang bersifat induktif [1]. Beban induktif adalah beban yang banyak menggunakan motor-motor listrik. Beban induktif menyebabkan rugi daya reaktif yang signifikan karena arus tertinggal. Sebagai tambahan, rendahnya ratio R/X pada sistem distribusi dapat menyebabkan rugi daya [2]. Peningkatan konsumsi daya reaktif menyebabkan arus jaringan yang lebih tinggi dengan penurunan tegangan yang tidak diizinkan. Akibatnya, sekitar $13 \%$ dari total daya yang dihasilkan hilang sebagai kerugian saluran listrik [3]. Salah satu cara yang paling efektif yang digunakan untuk mengurangi rugi-rugi daya pada sistem yaitu mengoptimalkan penggunaan kapasitor [4]. Pemasangan kapasitor menyebabkan arus yang mengalir pada penghantar menjadi lebih kecil. Akibatnya rugi-rugi daya dan penurunan tegangan pada sistem akan berkurang. Dalam pemasangan kapasitor perlu dipilih ukuran dan lokasi yang tepat sehingga penurunan rugi daya dan tegangan dapat dimaksimalkan [5].

Banyak metode yang digunakan untuk memecahkan masalah penempatan kapasitor. Metode kecerdasan buatan yang sering digunakan karena effisien dalam memecahkan masalah optimasi [6]. Pada penelitian sebelumnya, banyak metode yang telah dikembangkan untuk menyelesaikan masalah optimasi penempatan kapasitor antara lain menggunakan logika fuzzy, algoritma Artificial Bee Colony (ABC), algoritma genetika, dan kombinasi logika fuzzy - algoritma genetika. Masing-masing metode memiliki keuntungan dan kelebihan sehingga belum tentu metode satu lebih baik dari metode lainnya.

Pada penelitian ini akan mencari letak dan ukuran kapasitor yang optimal dengan metode logika fuzzyalgoritma genetika dengan menggunakan perangkat lunak MATLAB R2016b.

\section{Besaran Per Unit (pu)}

\section{DASAR TEORI}

Tegangan pada saluran transmisi tenaga listrik biasanya dioperasikan dalam kilo volt $(\mathrm{kV})$. Tegangan sering juga dinyatakan sebagai suatu presentase atau per unit dari suatu nilai dasar. Besaran per unit adalah perbandingan antara besaran sebenarnya dengan besaran dasar. Menentukan besaran per unit ditunjukan dalam persamaan 1. Tujuan pengunaan besaran per unit adalah mengurangi beban komputasi dalam proses analisis pada sistem tenaga listrik (menyederhanakan proses perhitungan) [7].

$$
\text { Per Unit }=\frac{\text { Actual }}{\text { Base }} \text {. }
$$

Dimana : Actual $=$ Besaran yang sebenarnya

\footnotetext{
${ }^{1}$ Program Studi Teknik Elektro, Universitas Kristen Maranatha
} 
Base = Besaran dasar

2. Kapasitor

Kapasitor adalah salah satu komponen elektronik yang digunakan untuk memperbaiki faktor daya. Dimana daya reaktif berpengaruh terhadap faktor daya. Kapasitor harus dipasang secara paralel dengan beban yang mengalami pengurangan faktor daya karena kapasitor adalah sumber dari beberapa atau semua daya reaktif yang diperlukan. Kapasitor menurunkan arus saluran yang mengalir ke beban dan juga mengurangi drop tegangan seperti yang diilustrasikan pada Gambar. 1 [5].

Kapasitor paralel mensuplai daya reaktif atau arus untuk menetralkan komponen keluaran antar fasa dari arus yang diperlukan oleh beban induktif. Penurunan tegangan pada feeder, atau pada saluran transmisi yang pendek dengan faktor daya tertinggal dan $I_{C}$ adalah arus kapasitor, ditunjukan oleh persamaan (2).

$$
V_{d}=I_{R} R+\left(I_{X}-I_{C}\right) j X_{L}
$$

Keterangan : $V_{d}=$ Penurunan Tegangan $(\mathrm{V}) ; \mathrm{R}=$ Resistansi total $(\mathrm{ohm}) X_{L}=$ Reaktansi total $(\mathrm{ohm}) ; I_{R}=$ Arus pada jaringan (A) $I_{X}=$ Arus reaktif lagging/tertinggal (A) $I_{C}=$ Arus reaktif leading/mendahului $(\mathrm{A})$

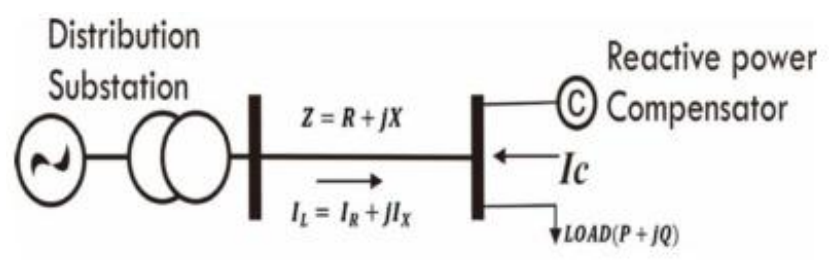

- Gambar 1. Pemasangan Kapasitor Paralel

\section{Aliran Daya Newton Raphson}

Analisis daya sistem tenaga listrik digunakan untuk menentukan parameter-parameter sistem tenaga listrik meliputi tegangan, daya, arus dan besar sudut fasa. Salah satu metode yang dipakai dalam menyelesaikan perhitungan aliran daya adalah metode newton raphson [8]. Metode ini menerapkan deret Taylor untuk mendapatkan turunan persamaan matematika sebagai dasar perhitungan iterasi yang melibatkan penggunaan matrik Jacobian.

\section{Logika Fuzzy}

Logika fuzzy adalah suatu cabang ilmu Artificial Intellegence, yaitu suatu pengetahuan yang membuat komputer dapat meniru kecerdasan manusia sehingga diharapkan komputer dapat melakukan hal - hal yang apabila dikerjakan manusia memerlukan kecerdasan. Logika Fuzzy umumnya diterapkan pada masalah masalah yang mengandung unsur ketidakpastian (uncertainty), ketidaktepatan (imprecise),noisy,

dan sebagainya. Logika Fuzzy menjembatani bahasa mesin yang presisi dengan bahasa manusia yang menekankan pada makna atau arti (significance). Logika Fuzzy dikembangkan berdasarkan cara berfikir manusia. Tahapan logika fuzzy yaitu $[9,10]$ :

1. Fuzzification (Membership Function)

Fuzzification merupakan suatu proses untuk mengubah suatu masukan dari bentuk tegas (crisp) menjadi fuzzy yang biasanya disajikan dalam bentuk himpunan - himpunan fuzzy dengan suatu fungsi keanggotaannya masing-masing.

2. Interference System (Fuzzy Reasoning)

Interference System (Fuzzy Reasoning) merupakan sebagai acuan untuk menjelaskan hubungan antara variabel - variabel masukan dan keluaran yang mana variabel yang diproses dan yang dihasilkan berbentuk fuzzy. Fuzzy reasoning biasanya dilakukan menggunakan if-then. 


\section{Defuzifikasi}

Defuzifikasi dapat didefinisikan sebagai proses pengubahan besaran fuzzy yang disajikan dalam bentuk himpunan-himpunan fuzzy keluaran dengan fungsi keanggotaannya untuk mendapatkan kembali nilai tegasnya (crisp).

Nilai indeks rugi - rugi daya (PLI) dapat dirumuskan dalam persamaan matematis sebagai berikut :

$$
P L I_{(n)}=\frac{\left(X_{(n)}-Y\right)}{Z-Y}
$$

Keterangan : $P L I=$ Indeks rugi - rugi daya $; X=$ Pengurangan rugi - rugi daya aktif

$Y=$ Pengurangan rugi - rugi daya aktif minimum

$Z=$ Pengurangan rugi - rugi daya aktif maksimum ; $\mathrm{n} \quad=$ nomor bus

\section{Algoritma Genetika}

Algoritma genetika adalah algoritma yang berusaha menerapkan pemahaman mengenai evolusi alamiah pada tugas - tugas pemecahan masalah. Pendekatan yang diambil oleh algoritma ini adalah dengan menggabungkan secara acak berbagai pilihan solusi terbaik di dalam suatu kumpulan untuk mendapatkan generasi solusi terbaik berikutnya yaitu pada suatu kondisi yang memaksimalkan kecocokannya atau lazim disebut fitness. Tahapan algoritma genetika ditunjukan pada Gambar 2 [11,12,13].

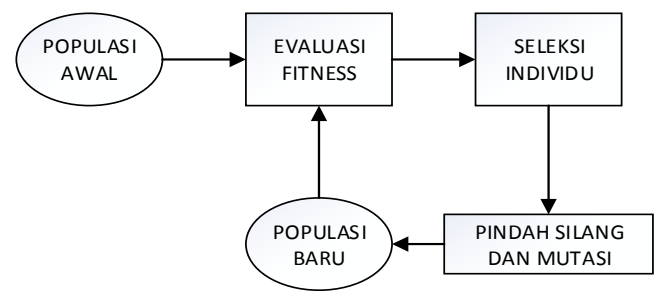

- Gambar 2. Siklus Algoritma Genetika

\section{METODOLOGI}

1. Metode Logika Fuzzy dan Algoritma Genetika dalam Menentukan Lokasi Kapasitor Optimal

A. Fuzzy Logic

Pada metode ini logika fuzzy digunakan untuk memilih kandidat bus dan algoritma genetika digunakan untuk menentukan besarnya ukuran kapasitor. Sebelum melakukan simulasi maka harus ditentukan dahulu beberapa parameter. Untuk Logika fuzzy ada beberapa parameter yang digunakan sebagai pertimbangan seperti power loss indices (PLI) atau indeks rugi - rugi daya seperti pada persamaan (3). Pada program simulasi ini kandidat bus dapat ditentukan sendiri tetapi sebaiknya mengacu pada indeks rugi - rugi daya. Pemilihan kandidat bus tergantung dari tujuan yang akan dicapai. Indeks rugi-rugi daya ini akan dijadikan input untuk logika fuzzy sebagai penentuan kandidat bus yang akan ditambahkan kapasitor. Gambar 3 menunjukan toolbox logika fuzzy pada Matlab R2016b.

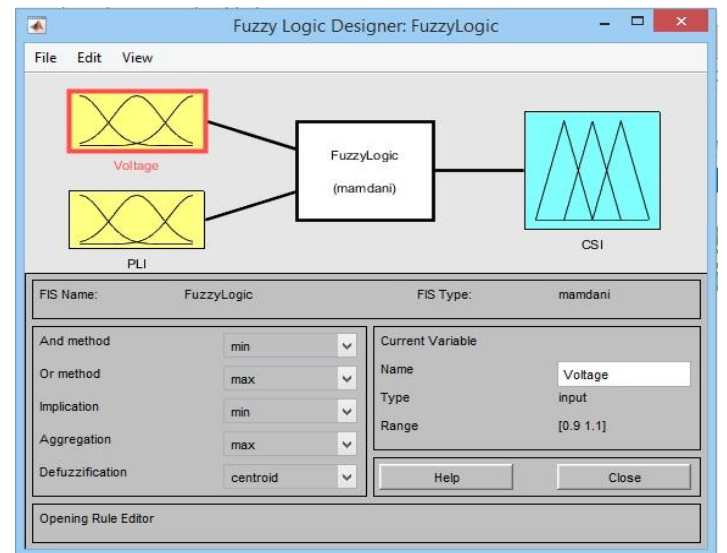

- Gambar 3. Tampilan Toolbox Logika Fuzzy Pada Matlab R2016b 


\section{B. Algoritma Genetika}

Algoritma genetika ini digunakan untuk menentukan ukuran kapasitor. Fungsi fitness dalam algoritma genetika ini meminimalkan rugi-rugi daya. Dalam menentukan ukuran kapasitor dilakukan 4 kali pengujian dalam setiap pengujian menggunakan parameter algoritma genetika yang berbeda. Parameter algoritma genetika yang digunakan yaitu populasi, maksimal generasi, peluang pindah silang dan peluang mutasi. Langkah-langkah dalam simulasi optimasi penempatan dan ukuran dengan fuzzy logic dan algoritma genetika akan ditunjukan dengan diagram alir pada Gambar 4.

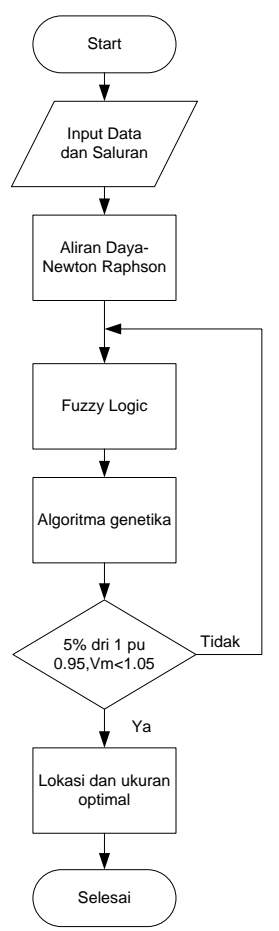

- Gambar 4. Diagram Alir Optimasi Fuzzy logic- Algoritma Genetika

\section{HASIL DAN PEMBAHASAN}

Data yang digunakan pada pengujian ini adalah data sistem jaringan tegangan menengah Region Jawa Barat. Bentuk jaringan sistem tegangan menengah region Jawa Barat ditunjukan pada Gambar 5.

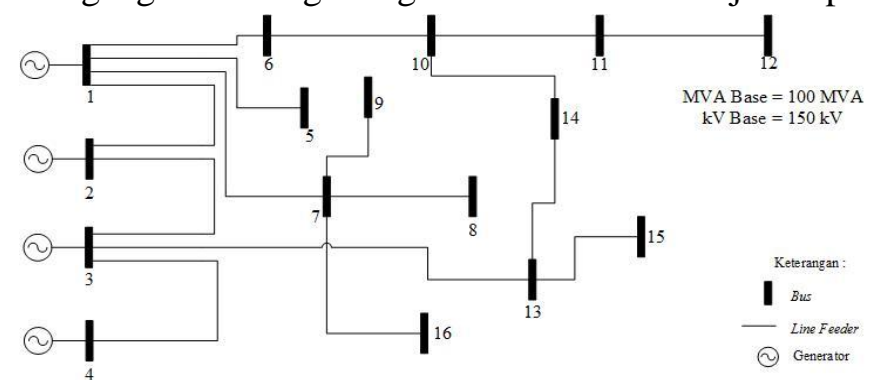

- Gambar 5. Bentuk Jaringan Sistem Tegangan Menengah Region Jawa Barat

Data yang diambil berupa data sistem kelistrikan yaitu data beban, data pembangkitan dan data saluran sistem ditunjukan pada Tabel 1. Pada Tabel 1 terdapat kode bus yang menunjukan jenis bus. Kode bus 1 yaitu bus 1 merupakan slack bus/ bus refrensi, kode bus 2 yaitu bus 2, 3, dan 4 merupakan bus generator dan kode bus 0 yaitu bus $3,4,5,6,7,8,9,10,11,12,13,14,15,16$ merupakan bus beban.

Tabel 1. Data Sistem Kelistrikan Region Jawa Barat

\begin{tabular}{cccccccc}
\hline \multirow{2}{*}{ Bus } & Bus & Voltage & Angle & \multicolumn{2}{c}{ Load } & \multicolumn{2}{c}{ Generator } \\
\hline No & Code & pu & Degree & MW & Mvar & MW & Mvar \\
\hline 1 & 1 & 1.05 & 0.0 & 84.18 & 18.00 & 0.00 & 0.00 \\
\hline 2 & 2 & 1.00 & 0.0 & 47.00 & 0.380 & 221.80 & 20.30 \\
\hline
\end{tabular}




\begin{tabular}{cccccccc}
\hline 3 & 2 & 1.00 & 0.0 & 20.00 & 20.00 & 201.40 & 26.20 \\
\hline 4 & 2 & 1.00 & 0.0 & 0.00 & 0.00 & 253.00 & 7.80 \\
\hline 5 & 0 & 1.00 & 0.0 & 48.00 & 18.00 & 0.00 & 0.00 \\
\hline 6 & 0 & 1.00 & 0.0 & 116.00 & 26.00 & 0.00 & 0.00 \\
\hline 7 & 0 & 1.00 & 0.0 & 142.00 & 52.00 & 0.00 & 0.00 \\
\hline 8 & 0 & 1.00 & 0.0 & 84.50 & 25.00 & 0.00 & 0.00 \\
\hline 9 & 0 & 1.00 & 0.0 & 106.00 & 34.00 & 0.00 & 0.00 \\
\hline 10 & 0 & 1.00 & 0.0 & 98.00 & 51.00 & 0.00 & 0.00 \\
\hline 11 & 0 & 1.00 & 0.0 & 30.00 & 6.00 & 0.00 & 0.00 \\
\hline 12 & 0 & 1.00 & 0.0 & 109.00 & 38.00 & 0.00 & 0.00 \\
\hline 13 & 0 & 1.00 & 0.0 & 67.00 & 14.00 & 0.00 & 0.00 \\
\hline 14 & 0 & 1.00 & 0.0 & 151.00 & 51.00 & 0.00 & 0.00 \\
\hline 15 & 0 & 1.00 & 0.0 & 92.00 & 10.00 & 0.00 & 0.00 \\
\hline 16 & 0 & 1.00 & 0.0 & 31.52 & 9.020 & 0.00 & 0.00 \\
\hline
\end{tabular}

1. Aliran Daya Sebelum Penempatan Kapasitor

Aliran daya dengan newton raphson merupakan langkah pertama untuk mendapatkan hasil tegangan tiap bus dan rugi-rugi pada saluran. Hasil aliran daya menunjukan terdapat 8 bus yang tegangannya berada dibawah 1 pu yaitu bus 6,9,10,11,12,13,14,15. Setelah analisis aliran daya maka dapat menentukan lokasi dan ukuran kapasitor optimal dengan fuzzy logic-algoritma genetika

2. Penentuan Letak Kapasitor dengan Fuzzy Logic

Penentuan letak kandidat bus dilakukan dengan logika fuzzy yang inputnya adalah tegangan pada bus dan PLI (Power Loss Index) dan outputnya adalah CSI (Capacitor Suitability Index). Nilai PLI dapat dihitung dengan Persamaan 3. Hasil perhitungan PLI (Power Loss Index) tiap bus akan ditunjukan dalam Tabel 2.

Tabel 2. Hasil Perhitungan PLI (Power Loss Index) tiap Bus

\begin{tabular}{cccccc}
\hline Bus & \multicolumn{3}{c}{ Power Loss } & Voltage & PLI \\
\hline No & MW & MVar & MVA & p.u & \\
\hline 1 & 496.662 & 474.973 & 687.221 & 1.050 & 1.0000 \\
\hline 2 & 174.800 & -144.257 & 226.639 & 1.000 & 0.5030 \\
\hline 3 & 181.400 & 209.62 & 277.212 & 1.000 & 0.5132 \\
\hline 4 & 253.300 & -77.457 & 264.878 & 1.000 & 0.6242 \\
\hline 5 & -48.000 & -18.000 & 51.264 & 1.045 & 0.1590 \\
\hline 6 & -116.000 & -26.000 & 118.878 & 0.987 & 0.0540 \\
\hline 7 & -142.000 & -52.000 & 151.222 & 1.038 & 0.0138 \\
\hline 8 & -84.500 & -25.000 & 88.1210 & 1.034 & 0.1026 \\
\hline 9 & -106.000 & -34.000 & 111.319 & 0.982 & 0.0694 \\
\hline 10 & -98.000 & -51.000 & 110.476 & 0.964 & 0.0818 \\
\hline 11 & -30.000 & -6.000 & 30.594 & 0.945 & 0.1868 \\
\hline 12 & -109.000 & -38.000 & 115.434 & 0.930 & 0.0648 \\
\hline 13 & -67.000 & -14.000 & 68.447 & 0.971 & 0.1296 \\
\hline 14 & -151.000 & -51.000 & 159.380 & 0.965 & 0.0000 \\
\hline 15 & -92.000 & -10.000 & 92.542 & 0.969 & 0.0910 \\
\hline 16 & -31.520 & -9.020 & 32.785 & 1.036 & 0.1845 \\
\hline
\end{tabular}

Hasil simulasi logika fuzzy pada bus 1 dengan Matlab R2016b ditunjukkan pada Gambar 6. 


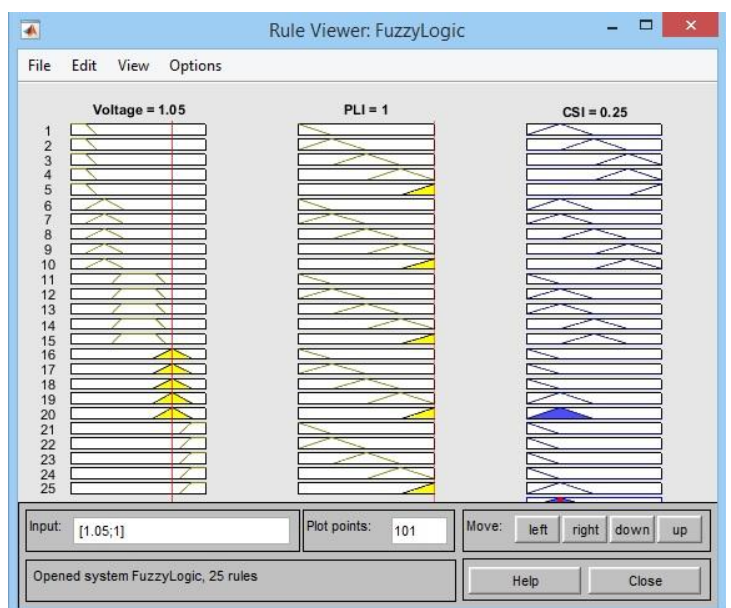

- Gambar 6. Contoh Hasil Logika Fuzzy pada Bus 1

- Tabel 3. Hasil Logika Fuzzy

\begin{tabular}{llll}
\hline Bus (No) & Voltage (pu) & PLI & CSI \\
\hline 1 & 1.050 & 1.0000 & 0.2520 \\
\hline 2 & 1.000 & 0.5030 & 0.2540 \\
\hline 3 & 1.000 & 0.5132 & 0.2680 \\
\hline 4 & 1.000 & 0.6242 & 0.3740 \\
\hline 11 & 0.945 & 0.1868 & 0.2520 \\
\hline
\end{tabular}

Hasil output logika fuzzy ditampilkan pada Tabel 3. Hasil penentuan kandidat bus mengacu pada CSI (Capacitor Sutability Index). Dilihat dari Tabel 3 tegangan pada bus 11 dan 12 berada di bawah $\pm 5 \%$ dan nilai CSI lebih dari 0.25 yaitu sebesar 0.2520 dan 0.3380 sehingga pada bus 11 dan 12 ditetapkan sebagai kandidat bus untuk penempatan kapasitor yang optimal. Selain bus 11 dan 12 terdapat bus yang memiliki nilai CSI lebih dari 0.25 yaitu, bus 1 sebesar 0.2520, bus 2 sebesar 0.2540, bus 3 sebesar 0.2680, dan bus 4 sebesar 0.3740. Bus tersebut tidak dipilih karena tegangan pada bus masih di ambang batas toleransi sebesar $\pm 5 \%$ dan juga bus 1 sampai dengan bus 4 merupakan slack bus dan bus generator. Bus yang harus dipasang kapasitor adalah bus beban. Bus 11 dan bus 12 diambil sebagai kandidat bus untuk penempatan kapasitor yang optimal.

\section{Pengujian Ukuran kapasitor Optimal dengan Algoritma Genetika}

Pengujian ukuran kapasitor dengan algoritma genetika dilakukan sebanyak 4 kali dengan memasukan nilai parameter algoritma genetika yaitu : jumlah populasi, maksimal generasi, peluang pindah silang, dan peluang mutasi. Penentuan parameter algoritma genetika menggunakan teknik Trial And Error dengan melakukan percobaan untuk beberapa kombinasi dari keempat parameter tersebut. Tabel 4 menunjukan hasil pengujian ukuran kapasitor dengan algoritma genetika.

- Tabel 4. Perbandingan Hasil Pengujian Ukuran Kapasitor dengan Algoritma Genetika

\begin{tabular}{|c|c|c|c|c|c|}
\hline Deskripsi & Sebelum & Pengujian 1 & Pengujian 2 & Pengujian 3 & Pengujian 4 \\
\hline $\begin{array}{c}\text { Total Kompensasi } \\
\text { (MVar) }\end{array}$ & 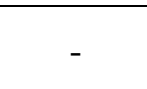 & 111.706 & 112.534 & 131.332 & 119.757 \\
\hline Posisi Kapasitor & - & Bus 11,12 & Bus 11,12 & Bus 11,12 & Bus 11,12 \\
\hline \multirow{4}{*}{$\begin{array}{c}\text { Perbaikan Tegangan } \\
(\mathrm{pu})\end{array}$} & Bus 11 & Bus 11 & Bus 11 & Bus 11 & Bus 11 \\
\hline & 0.945 & 0.987 & 0.988 & 0.994 & 0.986 \\
\hline & Bus 12 & Bus 12 & Bus 12 & Bus 12 & Bus 12 \\
\hline & 0.930 & 0.980 & 0.981 & 0.988 & 0.990 \\
\hline \multirow{4}{*}{$\begin{array}{c}\% \text { Perbaikan } \\
\text { Tegangan }\end{array}$} & & Bus 11 & Bus 11 & Bus 11 & Bus 11 \\
\hline & & $4.44 \%$ & $4.55 \%$ & $5.18 \%$ & $4.33 \%$ \\
\hline & & Bus 12 & Bus 12 & Bus 12 & Bus 12 \\
\hline & & $5.37 \%$ & $5.48 \%$ & $6.23 \%$ & $6.45 \%$ \\
\hline Perbaikan Tegangan & Bus 11 & Bus 11 & Bus 11 & Bus 11 & Bus 11 \\
\hline
\end{tabular}


Herawati, Ys, dan Gahara Nur E.P

\begin{tabular}{cccccc}
\hline (pu) & $\begin{array}{c}0.945 \\
\text { Bus 12 } \\
0.930\end{array}$ & $\begin{array}{c}0.987 \\
\text { Bus } 12 \\
0.980\end{array}$ & $\begin{array}{c}0.988 \\
\text { Bus } 12 \\
0.981\end{array}$ & $\begin{array}{c}0.994 \\
\text { Bus } 12 \\
0.988\end{array}$ & $\begin{array}{c}0.986 \\
\text { Bus } 12 \\
0.990\end{array}$ \\
\hline $\begin{array}{c}\text { Total Rugi Daya } \\
\text { Aktif (MW) }\end{array}$ & 31.142 & 29.585 & 29.585 & 29.626 & 29.615 \\
\hline $\begin{array}{c}\% \text { Penurunan Rugi } \\
\text { Daya Aktif }\end{array}$ & - & $5 \%$ & $5 \%$ & $4.868 \%$ & $4.903 \%$ \\
\hline $\begin{array}{c}\text { Total Rugi Daya } \\
\text { Reaktif (Mvar) }\end{array}$ & 128.859 & 121.350 & 121.336 & 121.162 & 121.305 \\
\hline $\begin{array}{c}\text { Presentase } \\
\text { Penurunan Rugi } \\
\text { Daya Reaktif }\end{array}$ & - & $5.83 \%$ & $5.827 \%$ & $5.973 \%$ & $5.862 \%$ \\
\hline
\end{tabular}

Dari hasil semua pengujian yang telah dilakukan dengan memasukkan kombinasi dari keempat parameter algoritma genetika dan batas toleransi tegangan yang ditentukan sebesar $\pm 5 \%$ (SPLN 72 : 1978) dapat disimpulkan bahwa kombinasi dari ke empat parameter algoritma genetika yang paling baik adalah pada pengujian 3 dengan jumlah populasi $=16$, maksimal generasi $=200$, peluang pindah silang $=0.95$, dan peluang mutasi $=0.007$ dengan lokasi penempatan kapasitor yang optimal adalah bus 11 (86.986 MVar) dan bus 12 (44.347 MVar) dan tegangan berhasil diperbaiki pada bus 11 sebesar 5.18\% dari 0.945 pu menjadi 0.994 pu, bus 12 sebesar $6.23 \%$ dari 0.930 pu menjadi 0.988 pu. Rugi - rugi daya aktif mengalami pengurangan sebesar 4.868\% dari 31.142 MW menjadi 29.626 MW, rugi - rugi daya reaktif juga mengalami pengurangan sebesar 5.973\% dari 128.859 MVar menjadi 121.162 MVar. Berkurangnya rugi - rugi daya aktif dan reaktif setelah penempatan kapasitor pada bus 11 dan 12 dapat memperbaiki tegangan secara signifikan karena tegangan pada bus yang lain (bus 6,10,13,14,15) mengalami perbaikan. Dengan demikian penempatan kapasitor pada bus 11 dan 12 sudah optimal.

Waktu hasil pengujian dari studi aliran daya dengan Newton-Raphson, penentuan letak kandidat bus akan dipasang kapasitor dengan logika fuzzy, dan penentuan ukuran kapasitor optimal dengan algoritma genetika membutuhkan waktu sekitar 4 menit.

\section{Hasil Perbandingan Sebelum dan Setelah Penempatan Kapasitor}

\section{A. Perbandingan Tegangan Sebelum dan Setelah Optimasi Penempatan Kapasitor}

Batas toleransi tegangan yang ditentukan sebesar $\pm 5 \%$ (SPLN $72: 1978$ ). Setelah penambahan kapasitor tegangan naik hingga $\geq 0.98$ pu. Perbandingan tegangan sistem sebelum ditambah kapasitor dan setelah ditambah kapasitor ditunjukan pada Gambar 7.

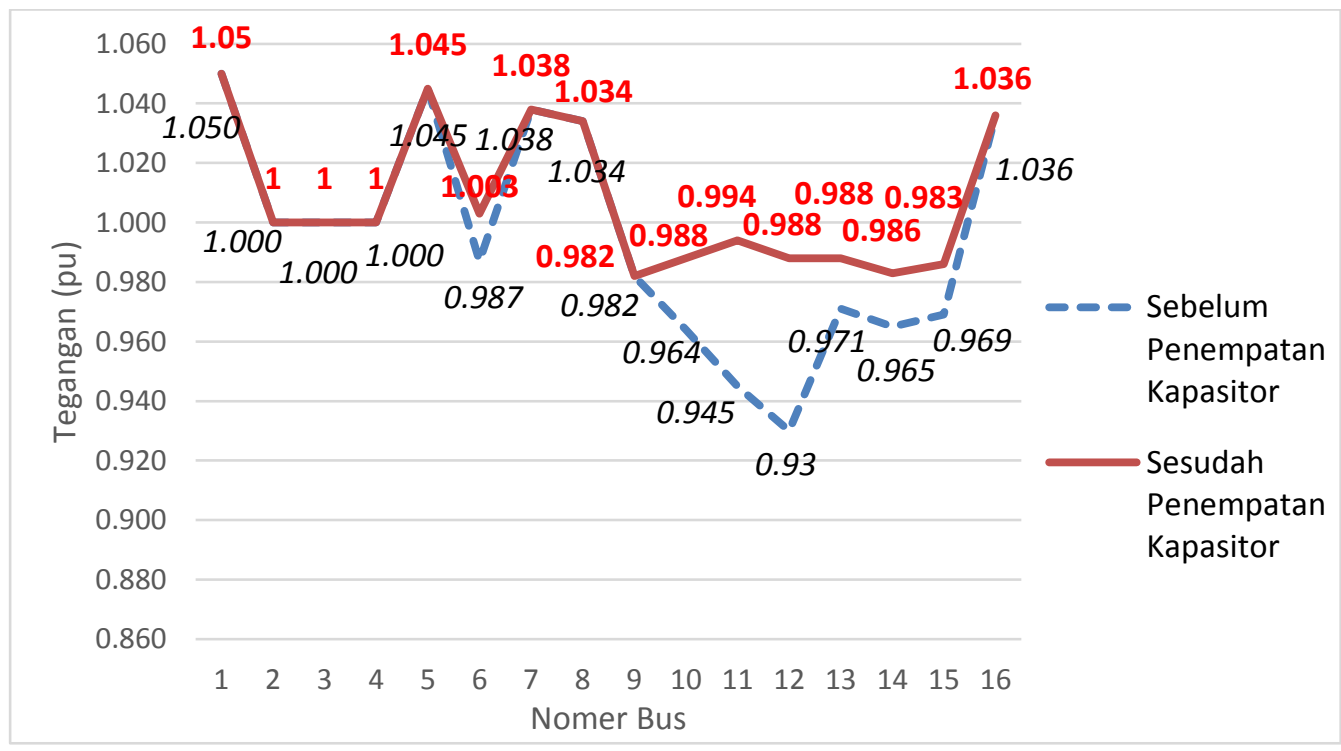

- Gambar 7. Tegangan Sebelum dan Sesudah Optimasi 
B. Perbandingan Rugi-Rugi Setelah Optimasi Penempatan Kapasitor dengan Fuzzy Logic-Algoritma Genetika

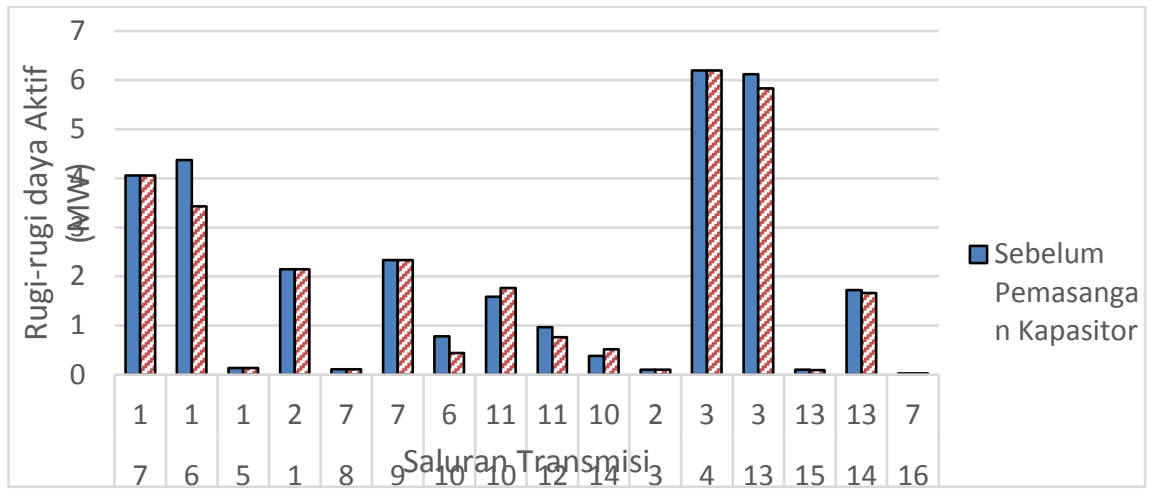

- Gambar 8. Rugi-Rugi Daya Aktif Sebelum dan Sesudah Optimasi

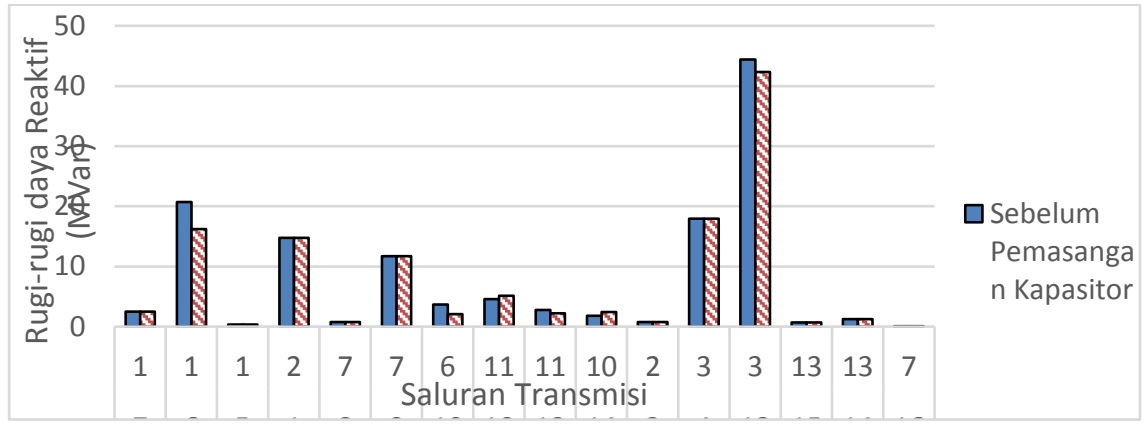

- Gambar 9. Rugi-Rugi Daya Reaktif Sebelum dan Sesudah Optimasi

Berdasarkan Gambar 8 dapat dijelaskan bahwa terjadi penurunan rugi-rugi daya aktif (MW) pada saluran 16, 6-10,11-12,3-13 dan 13-14. Berdasarkan Gambar 9 dapat dijelaskan bahwa terjadi penurunan rugi-rugi daya reaktif (MVar) pada saluran 1-6, 6-10, 11-12, 3-13. Penurunan rugi-rugi daya berhasil dikurangi tapi tidak signifikan karena pada beberapa saluran transmisi rugi-rugi daya tetap sama dengan sebelum penempatan kapasitor. Total rugi daya aktif sebelum penempatan kapasitor sebesar $31.142 \mathrm{MW}$ dan setelah penempatan kapasitor menjadi $29.626 \mathrm{MW}$ sehingga terjadi penurunan rugi daya aktif sebesar $4.868 \%$. Total rugi daya reaktif sebelum penempatan kapasitor sebesar 128.859 MVar dan setelah penempatan kapasitor menjadi 121.162 MVar sehingga terjadi penurunan rugi daya reaktif sebesar 5.973\%.

\section{KESIMPULAN}

Berdasarkan hasil pengujian dan data yang diperoleh dapat disimpulkan hal-hal sebagai berikut :

1. Lokasi penempatan kapasitor yang paling optimal dengan metode fuzzy logic-algoritma genetika yaitu bus 11 (86.986 MVar) dan bus 12 (44.347 MVar)

2. Tegangan pada bus 11 berhasil diperbaiki sebesar 5.18\% dari 0.945 pu menjadi $0.994 \mathrm{pu}$, bus 12 sebesar $6.23 \%$ dari 0.930 pu menjadi 0.988 pu.

3. Persentasi penurunan rugi - rugi daya aktif setelah kompensasi kapasitor adalah sebesar $4.868 \%$

4. Persentasi penurunan rugi - rugi daya reaktif setelah kompensasi kapasitor adalah sebesar $5.973 \%$

5. Waktu hasil pengujian dari studi aliran daya dengan Newton-Raphson, penentuan letak kandidat bus akan dipasang kapasitor dengan logika fuzzy, dan penentuan ukuran kapasitor optimal dengan algoritma genetika membutuhkan waktu sekitar 4 menit.

\section{DAFTAR PUSTAKA}

[1] S. W. Habsoro, A. Nugroho, and B. Winardi, "Analisa Penempatan Kapasitor Bank Untuk Perhitungan Drop Voltage Pada Feeder Batang 02 Tahun 2012-2016 Dengan Software ETAP 7 . 0 . 0,” J. Transient, vol. 2, no. 1, 2016. 
[2] R. M. Idris and N. M. Zaid, "Optimal Shunt Capacitor Placement in Radial Distribution System," IEEE, pp. 18-22, 2016.

[3] T. George, A. Youssef, M. Ebeed, and S. Kamel, "Ant Lion Optimization Technique for Optimal Capacitor Placement Based on Total Cost and Power Loss Minimization," IEEE, vol. 3, no. 1, pp. 350356, 2018.

[4] K. V. S. R. Murthy, M. R. Raju, and G. G. Rao, "Comparison between Conventional, GA and PSO with respect to Optimal Capacitor Placement in Agricultural Distribution System,” IEEE, pp. 3-6, 2010.

[5] A. Sello, E. Ervianto, and D. Y. Sukma, "Kajian Penempatan Kapasitor Bank Menggunakan Metode Genetika Algoritma Pada South Balam Feeder 1 PT. Chevron Pacific Indonesia," FTEKNIK, vol. 2, no. 1, pp. 1-8, 2014.

[6] M. Ayoubi, R. Hooshmand, and M. T. Esfahani, "Optimal capacitor placement in distorted distribution systems considering resonance constraint using multi-swarm particle swarm optimisation algorithm," IET Gener. Transm. Distrib., 2017.

[7] S Stevenson, William D. 1996. Analisis Sistem Tenaga Listrik. Jakarta : Erlangga

[8] E. Hosea and Y. Tanoto, "Perbandingan Analisa Aliran Daya dengan Menggunakan Metode Algoritma Genetika dan Metode," J. Tek. Elektro, vol. 4, pp. 63-69, 2004.

[9] Huddar Sujata, B. Kantharaj, K.R. Mohan, S.B. Patil, and Rudresh Magadum. "Optimal Location and Sizing of DG using Fuzzy Logic”, International Journal of Modern Engineering Research (IJMER), Vol 4, No. 6, June 2014

[10] Kusumadewi, Sri. 2002 “Analisa Desain Sistem Fuzzy Menggunakan Tool Box Matlab”. Jogjakarta: Graha Ilmu.

[11] Alamajibuwono, Hadha. 2011. "Optimasi Penempatan Kapasitor Menggunakan Algoritma Genetika pada Sistem Distribusi untuk Memperbaiki Faktor Daya dan Tegangan”. Semarang : Universitas Diponegoro

[12] Kurniawan, Unggul Dzackiy., Handoko, Susatyo., Winardi, Bambang. 2012. "Optimasi Penempatan Kapasitor Menggunakan Logika Fuzzy dan Algoritma Genetika Pada Sistem Distribusi Tenaga Listrik". Semarang : Universitas Diponegoro.

[13] Suyanto. 2005. Algoritma Genetika dalam MATLAB. Yogyakarta : Penerbit ANDI

[14] Gahara, "Simulasi Optimasi Penempatan Kapasitor menggunakan Logika Fuzzy dan Algoritma Genetika pada Sistem Tegangan Menengah Region Jawa Barat", Skripsi, Universitas Kristen Maranatha, Bandung,2017. 